\title{
From the editors
}

The disparity between strategic aspirations and affordable resources is a strategic reality confronting all militaries. Strategic aspirations tend to be international and foreign policy in orientation, whilst resource decisions are made in the context of the domestic political domain. Both these decision environments or realities may severely affect military forces as was dramatically illustrated recently by the military episode in the Central African Republic. The ordeal, in which fifteen South African servicemen were killed, not only brought South Africa's strategic aspirations in the spotlight; it also highlighted a range of perceived South African political, military and operational deficiencies. Some consider this to be South Africa's Srebrenicamoment and an opportunity for military strategic, operational and institutional introspection.

The recent budget vote by the South African Minister of Defence and Military Veterans, though, seemingly does not yet make provision for serious introspection in South African military outlook. The vote was, in fact, a continuation of the decline in the defence budget that has become a trademark of the current government since its rise to power in a democratic South Africa in 1994. The current 1,17 per cent of the gross national product that is allocated for defence, should be seen against the overall decline of defence as part of the country's national budget from 3,9 percent in the 2009/10 financial year to 3,6 percent in the 2013/14 financial year. If the South African government is serious about conflict prevention and stability on the continent and if South Africa still sees a hegemonic role for itself on the continent of Africa, the decline of its military capability ought to be taken seriously. Academics have a role in this regard and a responsibility to use forums like this journal to highlight further informed dialogue on these current and future challenges.

The article by Erwin Schwella on the lack of accountable public leadership, together with the article by Montesh and Mmusinyane on the establishment of the South African military ombudsman, places emphasis on the ethical foundation of the current security establishment in South Africa. The prevention of conflict and the conduct of war are social and people- or personnel-driven enterprises and therefore dependent on the accountable ethical behaviour of security institutions and their personnel. The Gupta saga that keeps appearing in the media the last couple of weeks, once again highlighted the need for both ethical and accountable military and political leadership for a successful and democratic South African. The saga also invokes questions on the potential influence of private capital or big business in the 
broader social realm in a country such as South Africa. Both articles place the emphasis on the conceptual and contextual nature of accountable public, military and security leadership and the need for awareness amongst officials of the importance of programmes to institutionalise and nurture ethical and accountable behaviour.

The article by Şerban Filip Cioculescu, from the Institute for Political Studies of Defence and Military History (Institutul Pentru Studii Politice De ApăRare şl Istorie Militară - ISPAIM) in Bucharest, stems from a joint South African-Romanian research project. On the South African side, the project was funded by the National Research Foundation of South Africa (NRF). This joint venture initiated by the Centre for Military Studies (CEMIS), under the aegis of the Faculty of Military Science, Stellenbosch University, situated at the Military Academy, Saldanha ran over three years. It was the first study of this nature undertaken in South Africa and Romania and represents pioneering work. The project included research workshops in both countries, the exchange of visiting scholars, student exposure to lectures and publications in journals and occasional papers in both countries as well as an edited work entitled South Africa and Romania: Transition to democracy and changing security paradigms edited by Calvin Manganyi, Ian Liebenberg and Thean Potgieter (Durban: Nexus Productions and Publications, 2012). As the first project in South Africa that involved a comparative study on transition from authoritarian rule to democracy, and changing security paradigms in Romania and South Africa, executed by two dedicated multi-national research teams, the concrete outcomes of the study augur well for the future. Romania and South Africa saw political transition to democracy at the same time, though through different modes of transition. In the resultant security transformation and in their new defence posture and diplomatic orientation, these countries made different choices: Romania entered NATO and South Africa moved away from distinct alignment with any power blocs when it comes to a defence posture, rather choosing a (Pan-)African focus and bilateral relations over the political spectrum (South Africa's membership of BRICS is one example. South Africa's deployment of peacekeepers in various African countries offers another). Cioculescu's article enlightens us on political and security developments in Romania as a previous East bloc country and now member of NATO.

The article by Lyndelle Joubert focuses on a strategic important matter, not only for South African security, but for security in Africa. Maritime terrorism and piracy in the Horn of African and the Gulf of Guinea have become one of the most heavily debated issues on the African and international security agenda. Africa is, at present, going through a period of tremendous economic development and growth 
that is rooted in a global interest in African markets and a demand for African resources. The integration and globalisation of the African economy through the growth of both the African marketplace and the export of its resources and, increasingly, also African production, is dependent on access to Africa's maritime infrastructure and the safety of its coastline. Even though the links between piracy and maritime terrorism seem to be limited or non-existent, the possibility cannot be excluded. If Africa is serious about its economic growth, security and social development, the continent cannot afford to be drawn into the so-called Global War on Terror. Thus, Africa needs to form part of the global debate on and solution for maritime terrorism and piracy.

The Anglo-Boer War (1899-1902) drew international attention. Countries like Russia, the Netherlands, Portugal, Germany and France viewed it with interest, and volunteers from Scandinavia, Russia, the Netherlands, Germany, France, Ireland and a sprinkling of Irish-Americans fought on the Boer side. The superb article by Henk de Jong provides a glimpse of how internationalised the so-called South African or Anglo-Boer War had been with an analysis of the Dutch military observers on the Boer side during the war, and their reporting on the war in the Netherlands. The conduct of war in this far-off anti-colonial struggle also drew attention. It is fascinating to note that the four Dutch military observers approached their reporting on the South African War with a strong emphasis on the search for the Jominianstyle decisive battle. Like most European armies of the time, they missed the fundamental changes in the conduct of war that were brought about by new technology. Instead, the Dutch military observers highlighted the new Clausewitzian trinity they observed in the Boer society. This led the observers, De Jong claims, to argue in favour of a fundamentally new relationship between the army and society in Holland, and a new Dutch militia army organisation, comparable to the Boer commandos. The article, though, is also interesting to read from a historiographical point of view. Not only does De Jong provide insights into the way military practitioners deal with the interplay between the past, present and future, but he also draws interesting historical parallels between Boer and Dutch societies and between Afrikaner and Dutch past, future and present lasting relationships and debates over at least two centuries.

In the current age of austerity, Scientia Militaria - The South African Journal of Military Studies, like other academic journals, is confronted with decisions about its future financial management. At a recent meeting of the Editorial Board, a decision was reached about page fees. In view of this decision, a page fee of ZAR75,00 per page would be instituted for contributors. Students, independent researchers and 
authors from outside South Africa are exempted from this arrangement. Hopefully, this would not affect continued support from the academic fraternity for the journal.

The editors

Abel Esterhuyse \& Ian Liebenberg 